find him "as easy as an old shoe". And so it proved.

We worked together until I left in 1983 with only one cross word (entirely my fault) and shared a one-in-two rota without conflict. He never complained about his workload, was always accommodating and flexible and quite remarkably cheerful. He had only a nodding acquaintance with the clock but his patients gladly adjusted. A phobic dislike of dictating machines limited the quantity of his letters but he was the most accessible of consultants: communication with him was always easy, informative and pleasant. As time went on he took an increasing role in the management of the West Cumberland Hospital and gathered a respect not always given to psychiatrists in a district general hospital. Moreover, he became the psychiatrist of choice to medical families in the area and carried that gratifying but arduous role of being the doctor's doctor.

He was an extremely pleasant, gentle, rather shy, large man, humorous and generous. His home was always full of music and laughter. A diligent and skilled gardener, he skied in the winter and sailed in the summer (for some years he had his own yacht on the uncertain waters of the Solway) loved fast cars, was widely read and very knowledgeable about art. His great passion was for music, particularly opera, and he was a competent but private clarinettist.

He retired in 1988 but could not abandon the work habit and did a series of locum jobs in Cumbria and North Lancashire in general psychiatry, psychogeriatrics and child and adolescent psychiatry until he finally stopped in 1995 He had increasing health problems over the last 2 years of his life but made no fuss about them and led a life of activity to the edge of tolerance.

He met his wife Mira when they were both in their teens and their marriage was the envy of their friends. In addition, he leaves four charming and successful daughters who inevitably include a social worker and a doctor.

Tony Drummond

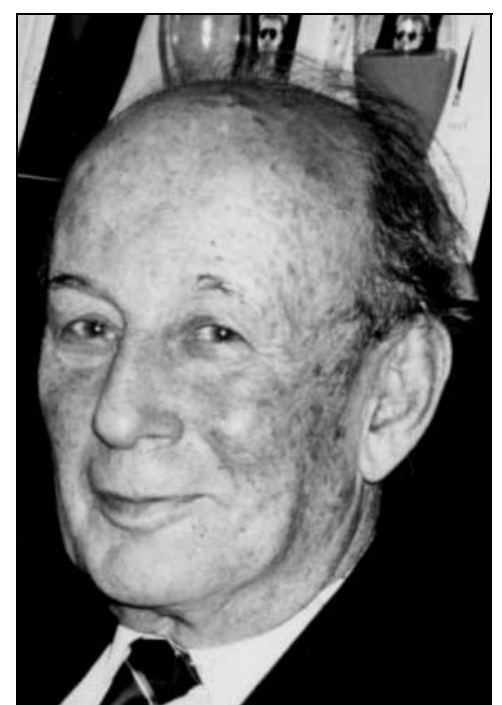

\section{Thomas Galla}

Former Consultant Psychiatrist North Staffordshire Hospital Centre

Thomas Galla, who died from a cerebral tumour on 11 February 2001, was born in Budapest on 12 June 1923. In the autumn of 1938 his parents arranged, with the help of a Scottish clergyman in Hungary, for Tom to be accepted at the Dollar Academy in Clackmannanshire. Tom, aged 15, arrived at the Dollar knowing only a few words of English, but with intensive tuition from his housemaster he rapidly learned the language. Against the advice of his parents he returned to Budapest for the summer holiday and left again in September 1939 "with only about 12 to 15 hours before it would have become impossible".

After 2 further years at the Dollar Academy he won the class prize in English and was subsequently awarded a scholarship to study medicine at Edinburgh University. His parents (who died during or shortly after the war) had both been doctors and it had always been his ambition to follow in their footsteps. He graduated MBChB in 1947. After house jobs and National Service in the Royal Army Medical Corps in Singapore, where he was a graded psychiatrist, he came to Stoke-on-Trent in 1952 as the first psychiatric registrar in the psychiatric unit of the City General Hospital. He completed his psychiatric training as senior registrar in the Bristol Mental Hospitals and returned to Stoke-on-Trent in 1957 as Consultant Psychiatrist and Deputy Superintendent of St Edward's Hospital, Cheddleton. He had obtained the DPM (England) in 1954 and became FRCPsych in 1971.

In 1969, Tom was appointed Chairman of the St Edward's Hospital Medical Staff Committee, a post he occupied until he retired in 1989. In this post he carried out assiduously, and without remuneration, the duties of what were, in fact, those of a superintendent, uncomplainingly spending long hours sorting out staffing and administrative problems. At the same time he carried a full clinical load and, later, a busy private practice and his opinion was eagerly sought by solicitors from North Staffordshire and further afield as he had built up a considerable reputation as an expert in forensic psychiatry.

Tom was a highly intelligent, modest and unassuming man. He played chess for the County of Staffordshire, was an ardent supporter of Stoke City Football Club and had a keen interest in music, literature and travel. In recent years he had, by his own account "become very active in the grandfather business", a role that he embraced with great enthusiasm. He had a dry sense of humour and a vast fund of humorous stories; as a friend and colleague for 35 years' duration I shall miss hearing the latest joke from him. An astute clinician and able administrator, he made a significant contribution to psychiatry in North Staffordshire.

In 1948 Tom married Mary Benecke whom he had met when she was a nurse at the Western General Hospital in Edinburgh. The marriage was a very happy one and they were blessed with two sons, Andrew and Max. Sadly, Mary died in 1984, a loss that left Tom badly shaken but in which he was sustained by his family, good friends and his ability to lose himself in his work. He is survived by his sons and two grandchildren, with one more on the way.

Edward Myers

\title{
corrigenda
}

On page 288 of the article written by

A. M. Mortimer (Psychiatric Bulletin,

August 2001, 25, 287-288) the

corresponding address and title of the author are incorrect. The following is correct: Professor Ann Mortimer, The University of Hull, East Riding Campus, Department of Psychiatry, Coniston House, Beverley Road, Willerby, Humberside HU10 6NS
On page 400 of the October issue, the name of the first author, Tom Picton, was omitted from the letter 'Donezepil and those with learning disabilities' (Psychiatric Bulletin, October 2001, 25, 400). 